\title{
"Imperial Habit": Russia's Attempt to Gain a Foothold on the Eastern Coast of the Caspian Sea in the Era of Peter the Great
}

\section{Ilya V. Toropitsyn}

Astrakhan State University. Astrakhan, Russia. Email: itoropitsyn[at]mail.ru

\section{Abstract}

The article displays one of the directions of Russia's foreign policy during the reign of Peter the Great, namely, an attempt to gain a foothold on the Eastern coast of the Caspian Sea for further advancement through the Central Asian states to India in order to establish direct trade relations. The paper analyzes the goals and objectives set up by Peter the Great to Prince A. Bekovich-Cherkassky to initiate a new trade route to India from the Caspian Sea basin. Russia's steps aimed at creating a foothold on the Eastern coast of the Caspian Sea are being considered. The adopted scientific ideas about the number of strongholds in the Caspian region founded by Russia in 1716 are analyzed. The Russian-Turkmen relations are described during the period of Russia's activity in the Caspian region and after the failure of the Khiva expedition of 1717. The fate of Russian fortress-cities in the eastern Caspian region is traced. The assessment of the actions of Prince

A. Bekovich-Cherkassky on the implementation of Russia's policy in the Caspian region is given in the context of Peter the Great's plans.

\section{Keywords}

Eastern policy of Russia; the Caspian Sea; Peter I; Prince A. Bekovich-Cherkassky; Fortress-Cities; Turkmens; 18th century

This work is licensed under a Creative Commons "Attribution" 4.0 International License 


\section{«Имперская замашка»: попытка России закрепиться на Восточном побережье Каспийского моря в эпоху Петра I Великого}

\section{Торопицын Илья Васильевич}

Астраханский государственный университет. Астрахань, Россия. Email: itoropitsyn[at]mail.ru

\section{Аннотация}

Статья посвящена одному из направлений внешней политики России во времена царствования Петра I Великого, связанному с попыткой закрепиться на Восточном побережье Каспийского моря для дальнейшего продвижения через среднеазиатские государства в Индию с целью налаживания прямых торговых связей. В публикации анализируются цели и задачи, поставленные Петром I перед князем А. Бековичем-Черкасским по налаживанию нового торгового маршрута в Индию из бассейна Каспийского моря. Рассматриваются шаги России по созданию плацдарма на Восточном побережье Каспийского моря. Анализируются устоявшиеся в науке представления о количестве опорных пунктов в Прикаспии, заложенных Россией в 1716 году. Характеризуются русско-туркменские взаимоотношения в период активизации России в Каспийском регионе и после неудачи Хивинской экспедиции 1717 г. Прослеживается судьба русских крепостей-городов в восточном Прикаспии. Дается оценка действиям князя А. Бековича-Черкасского по реализации политики России в Прикаспии в контексте замыслов Петра I.

\section{Ключевые слова}

Восточная политика России; Каспийское море; Петр I; князь А. Бекович-Черкасский; городакрепости; туркмены; XVIII в.

Это произведение доступно по лицензии Creative Commons “Attribution” («Атрибуция») 4.0 Всемирная 
Journal of Frontier Studies. 2022. No 1 | ISSN: 2500-0225

Empire on the Move | https://doi.org/10.46539/jfs.v7i1.367

\section{Вступление}

В правление Петра I Россия проводит чрезвычайно активную внешнюю политику, направленную на приобретение новых территорий, обеспечение выхода к мировым транспортным коммуникациям и новым торговым рынкам и преследующую в конечной цели рост своего авторитета на мировой арене.

В исторической литературе неоднократно отмечали характерные особенности внешней политики Петра I. «Все войны, какие только вел в свое царствование Петр Великий, имели своей целью приобретение морских берегов: черноморских (азовских), балтийских и каспийских, - пишет С.Ф. Платонов. Гениальный политик рвался к морям, понимая, какое значение имеют моря в международных отношениях, в движении культуры» (Платонов, 1917, с. 286).

Политика Петра I в полной мере соответствовала эпохе Нового времени. Ведущие мировые державы проводили активную колониальную экспансию, особое место в которой отводилось Индии. «Всем известно, - отмечает по этому поводу С.Ф. Платонов, - какое важное значение играл Восток в экономическом развитии Европы, как упорно стремились европейцы узнать пути к конечной цели торговых вожделений - Индии» (Платонов, 1993, с. 507).

Пётр I, побывав во многих европейских странах, познакомившись с деятельностью Голландской Ост-Индской компании, антверпенской биржи, имел вполне четкое представление о том, за счет чего богатели Великобритания, Голландия и другие колониальные империи того времени. «В Голландии компанейския предприятия приносили тогда огромный доход участникам, - пишет С.А. Князьков, - успехи Ост-Индской компании в Англии и французской для торговли с Америкой были тогда у всех на языке» (Князьков, 1914, с. 318).

Судя по всему, Пётр I и сам был не прочь принять участие в дележе богатств Востока. К такому выводу подталкивает его реакция на предложение сибирского губернатора князя М.П. Гагарина овладеть городом Эркети в Малой Бухарии, вблизи которого якобы протекала река, несущая золотой песок. Это предложение встречает полную поддержку российского самодержца. 22 мая 1714 г. Пётр I собственноручно начертал на предложении князя М.П. Гагарина:

«Построить город у Ямышева озера и буде можно и выше и, построя крепость, искать далее по той реке вверх, пока лодки пройти могут и оттоль идти далее до города Эркета и оным искать овладеть» (Жуковский, 1915, с. 46).

Как видим, Петра I в данной ситуации нисколько не смущал тот факт, что своими действиями он, по сути, санкционировал начало новой военной кампании. Объяснение той удивительной лёгкости, с которой Пётр I готов был начать завоевание золотоносной реки в Малой Бухарии и города Эркети, следует искать не столько в текущих финансовых потребностях российского государства, ведущего войну со Швецией, сколько во взглядах Петра I на Азию в целом. Е.В. Анисимов пришел к убеждению, что Петр I поначалу был 
во власти типичного европоцентристского представления о Востоке как некоем общем пространстве, где живут «дикие азиатцы», которые не в состоянии ничего противопоставить регулярной армии европейского образца, и с которыми можно справиться ограниченным контингентом войск (Анисимов, 2019, с. 14).

Дополнительным фактором, усилившим интерес Петра I к проекту сибирского губернатора, стала позиция хивинского посла Ашур Бека, находившегося в то время в России, который подтвердил показания князя М.П. Гагарина и предложил Петру I построить крепость вблизи того места, где прежде река Аму-Дарья впадала в Каспийское море (Жуковский, 1915, с. 46-47).

Предложение хивинского посла попало на благодатную почву. Петр I придавал большое значение владению опорными пунктами на морском побережье в целях развития международной торговли. «Умножение флота имеет единственно целью обеспечение торговли и пристаней, - говорил Петр I, - ... пристани необходимы для государства, ибо чрез сих артерий может здравее и прибыльнее сердце государственное быть» (Князьков, 1991, с. 156).

Идея утвердиться на Восточном побережье Каспийского моря показалась Петру I весьма привлекательной. «Царь понимал, - пишет С.В. Жуковский, что если и не найдется искомое в реках золото, то по крайней мере найден будет новый способ к получению его посредством торговли через страны с самою Индиею» (Жуковский, 1915, с. 47). Как мы увидим, данное соображение не было лишено оснований.

\section{Методология исследования}

Восточная политика России в первой четверти XVIII в. неоднократно привлекала интерес исследователей. Авторы обращают внимание на различные аспекты петровских начинаний, не упуская из виду и его замыслы в отношении Каспийского бассейна. Как правило, в исследованиях рассматриваются причины, пробудившие интерес Петра I к поиску пути из Каспийского моря в Индию, анализируются поручения, данные российским самодержцем участникам каспийских экспедиций, характеризуются с разной степенью полноты ход и итоги данных экспедиций, попытки посланцев Петра I наладить дипломатические контакты с Индией через страны-посредники, а также общий итог Хивинской экспедиции 1717 г.

Первые оценки планам и шагам Петра I в этом направлении дал Ф.И. Соймонов, непосредственный участник экспедиций на Каспийском море, а впоследствии и Персидского похода 1722-1723 гг.: «Он желал по овладении Восточного берега Каспийского моря доставать песошное золото во свою землю чрез купечество. Также казалось, что великое его намерение, открыть России новую для торгов дорогу в Индию, чрез то в действие приведено быть может» (Соймонов, 1763, с. 7). 
И.И. Голиков также отмечает страстное желание Петра I распространить торговлю своих подданных «и обратить в любезную свою Россию все источники богатств и познаний». Именно с этой целью Петр I, по его мнению, определил выяснить все о золоте в реках, текущих в Среднюю Азию, и поставил задачу «о разпространении как власти своея в тамошних краях, так и торговли до самыя Индии» (Голиков, 1788, с. 124).

K концу XIX в. по данному вопросу имелась уже обширная библиография, которую рассмотрел в своей работе И.Г. Безгин. Он провел обзор сведений, касающихся каспийских экспедиций и похода в Хиву в 1717 г. князя А. БековичаЧеркасского. В его исследовании были зафиксированы как сведения, заимствованные из документальных источников, так и из различных публикаций. Но по сути И.Г. Безгин ограничился лишь констатацией фактов без какого-либо их анализа (Безгин, 1891).

Заложенные в XVIII-XIX вв. традиции освещения политики России в Каспийском регионе в петровский период были продолжены последующими поколениями отечественных ученых (Павленко, 1976, с. 294-297; Мавродин, 1988, с. 137-138; Буганов, 1989, с. 174-177; Платонов, 1993, с. 507). При этом в большинстве исследований судьба русских городов, основанных на Восточном побережье Каспийского моря в ходе экспедиций А. Бековича-Черкасского, затрагивалась лишь в контексте общих сведений о Хивинской экспедиции 1717 г. Более того, в трудах советских историков приводятся различные данные о количестве городов, заложенных князем А. Бековичем-Черкасским, что говорит об отсутствии единого представления в исторической науке советского периода по данному вопросу.

Из современных работ этой теме посвящена публикация авторского коллектива: А.Х. Даудов, А.А. Андреев, Д.Г. Янченко, В.А. Шорохов, А.С. Кибинь. Данные исследователи затронули многие важные аспекты, в частности, поставили под сомнение утверждения многих своих предшественников о количестве крепостей, основанных в Восточном Прикаспии в петровское время, остановились на состоянии русско-туркменских отношений, попытались проследить судьбу русских крепостей после гибели Хивинской экспедиции 1717 г. (Даудов, Андреев, Янченко, Шорохов, Кибинь, 2016). Авторы привлекли широкий круг источников, но осветили вопросы с разной степенью полноты.

Анализ историографии показывает, что взгляды авторов на политику России в Каспийском бассейне в первой четверти XVIII в. в целом совпадают, но отличаются в некоторых важных деталях. Это обусловлено как объемом привлекаемых ими источников, так и их характером. В зависимости от того, опираются авторы на первоисточники или трактуют события без привязки к ним, экспедиции России на Восточное побережье Каспийского моря и в Хивинское ханство, попытка проникновения из этого региона в Индию, взаимоотношения с туркменскими племенами рассматриваются ими с разной степенью глубины. 
Все эти аспекты делают рассмотрение вопроса о попытке России закрепиться на Восточном побережье Каспийского моря в эпоху Петра I Великого по-прежнему актуальным.

\section{Создание на каспийском побережье опорных пунктов для продвижения в Азию}

В историографии отмечается давнее стремление Петра I превратить Россию в торговую посредницу между восточными и западными странами (Князьков, 1914, с. 338; Павленко, 1976, с. 294; Мавродин, 1988, с. 137). Поэтому не удивительно, что Пётр I при первой же возможности ухватился за идею проложить маршрут в Индию из бассейна Каспийского моря через территорию Средней Азии.

Реализация этого смелого замысла была поручена Петром I капитану Лейб-гвардии Преображенского полка князю А. Бековичу-Черкасскому. Добиться желаемого результата Пётр I планировал путем взятия под контроль торгового пути вдоль русла реки Аму-Дарьи. В его указе от 14 февраля 1716 года князю А. Бековичу-Черкасскому первым пунктом значилось: «Надлежит над гаваном, где бывало устье Амму-Дарьи реки, построить крепость человек на тысечю, о чем просил и посол хивинской» (Гистория, 2004, с. 584). По пути в Хивинское ханство А. Бекович-Черкасский должен был следовать вдоль русла «той реки», осматривая его и примечая плотину. Возле нее «или где удобно» по течению Аму-Дарьи надлежало присмотреть «тайным образом» место для строения еще одной крепости, «а буде возможно будет, то и другой город зделать» (Гистория, 2004, с. 585).

Важная роль при этом отводилась установлению протекционистских отношений с правителем Хивинского ханства и дружественных - с ханом Бухарского ханства. «Петр знал, что ханы Средней Азии находятся в очень печальном положении под влиянием местных партий и честолюбцев, - пишет С.В. Жуковский, - и задумал упрочить власть и независимое положение ханов при помощи русских отрядов, которые ханы содержали бы при своих дворах на свой счет, следствием чего было бы то, что ханы явились послушным орудием воли русского царя» (Жуковский, 1915, с. 48).

Политическая часть плана с самого начала вызвала сомнения у князя А. Бековича-Черкасского. Он высказал их Петру I, который постарался их развеять: «Что же пишешь - ежели хан хивинский не склонится, и я не могу знать в чём, только велено вам, чтоб в дружбе были и чтоб купчину послать водою в Индию и ежели надобна им гвардия; только о гвардии не похотят, и то в их воле, а в дружбе, чаю, не откажут». В случае всё-таки отказа хивинского хана от предложенной Россией «дружбы» Пётр I призывал князя А. Бековича-Черкасского сконцентрировать внимание на строительстве городков и установлении водной коммуникации с Хивинским ханством: 
«только что те два города делай, и плотину разори, и по реке вверх, сколько время допустит, и смотри токо её» (Соловьёв, 1993, с. 342).

Таким образом, можно видеть, что Пётр I не был до конца уверен, что удастся склонить хивинского хана к принятию российских условий, однако, все равно рассчитывал установить водный путь из Каспийского моря в Хивинское ханство и взять его под свой контроль. По всей видимости, Петра I вполне устраивал тот факт, что своими действиями Россия вмешивалась в дела соседних народов. Впрочем, по мнению Е.В. Анисимова, для Петра I это было вполне естественно. «Великая восточная мечта Петра могла быть реализована не просто с помощью налаживания торговых отношений, - пишет Е.В. Анисимов, - но и неизбежной территориальной экспансией. Так делали все великие колониальные державы того времени, и Пётр мыслил свою империю именно империей мирового уровня» (Анисимов, 2019, с. 13).

Для экспедиции назначалось 4 тысячи «регулярных» человек. Строить город должны были полторы тысячи яицких и пятьсот гребенских казаков вместе с сотней драгун под началом «доброго командира». Этому командиру приказывалось «накрепко смотреть, чтоб со обыватели земли ласкова и бес тягости обходился». Для проведения строительных работ приказано было взять в поход «несколько лопаток и кирок» (Гистория, 2004, с. 585).

По получении указа князь А. Бекович-Черкасский обратился в Сенат с требованием выделить ему 1500 драгун и 2500 солдат, а также 2000 казаков. «Оному войску денежное жалованье, амуницы, правианту, мундиру надобно на три года», - писал он (Гистория, 2004, с. 586).

Сенат распорядился направить в распоряжение князя А.Б. Черкасского два солдатских полка, численностью по 1200 человек, один из Казани, другой из Астрахани. Еще 400 человек собрать для экспедиции из Поволжских городов. Третий полк (1200 человек) решено было направить из Азовской губернии, а также послать 100 человек из Астраханского «шквадрона». Для градостроительных целей было отпущено 1638 лопат, 1500 заступов, 650 кирок и 500 топоров. Для перевозки этих сил к Восточному побережью Каспийского моря велено было дать все готовые суда, имевшиеся налицо в Казани, Астрахани и вообще в низовых городах Волжского бассейна, а также строить новые. Князю А. Бековичу-Черкасскому вменено было в обязанность ограничиться «самою необходимою постройкою новых судов, дабы не вводить казну в излишние издержки и не замедлить с отправлением экспедиции». Для этого он должен был использовать готовые суда два или три раза для перевозки войск и продовольствия (РТО, 1963, с. 47).

15 сентября 1716 г. на этих судах три полка отправились в поход и 9 октября пришли к урочищу Тюк-Караган. Здесь князь А. Бекович-Черкасский велел сойти на берег Казанскому полку полковника Ф.С. Хрущева, разбить лагерь и приступить к строительству города, названного впоследствии крепостью Святого Петра. 
По мнению поручика А. Кожина, выбранное начальником экспедиции место под «строение города непотребно, понеже не имеет ни земли, ни лесу, ни воды свежей, токмо один песок, которой насыпан от моря». «А которую воду копают ис песку, - отмечал А. Кожин, - и та соленая, малым отменна от морской». А. Кожин обратил внимание на то, что «к тому месту никаких путей ис Хивы и из других мест не подлежит». Отправленные для исследования сухопутного пути в Хиву астраханцы И. Воронин и А. Святой говорили, что маршрут от этой крепости до хивинских владений «гористый, что телегою проехать не мочно, да и со вьючными верблюдами с нуждою». (Гистория, 2004, c. 604).

23 октября флотилия князя А. Бековича-Черкасского двинулась дальше вдоль Восточного побережья Каспийского моря до Красных вод. 3 ноября она прибыла в назначенное место. А. Кожин дал и ему нелестную характеристику: «на том мысу ни лесу, ни воды свежей, ни травы нет же, кроме той травы, которою верблюдов кормят... при том же пришол глухой залив, где вода морская стоячая и вонючая» (Гистория, 2004, с. 604).

Несмотря на то, что вблизи того места не было следов реки, впадающей в Каспийское море, князь А. Бекович-Черкасский приказал полковнику фон дер Видену строить город. По свидетельству прапорщика Коротояцкого полка Ф. Исингельдеева, князь А. Бекович-Черкасский в Красноводском урочище на песочной косе велел «очертить при себе инженерного дела ученику земляную крепость и, очертя оную, приказал делать солдаты» (РТО, 1963, с. 41).

По поводу принятых решений среди командного состава вышел спор. «Будучи де у Красных вод, ему, князю Черкаскому, он, Кожин, и штап-офицеры говорили, что велит строить городы и людей оставляет в неудобных местах» (Гистория, 2004, с. 604). Но руководитель экспедиции своего решения не поменял. По словам Ф. Исингельдеева, князь А. Бекович-Черкасской, заявил им: «воду пресную и лес сыскать можете и после меня», и объявил, что возвратится к ним из Астрахани в 1717 г. весной или в начале лета. Таким образом, строить город-крепость у Красных вод были оставлены два других полка, и «оная ж крепость делана на неудобном пещаном месте и пресной воды и лесов никаких на той косе нет» (РТО, 1963, с. 41).

В историографии присутствуют разные данные о количестве городов, заложенных в 1716 г. на Восточном побережье Каспийского моря. В.И. Буганов упоминает только об одной крепости (Буганов, 1989, с. 175). Н.П. Ламбин и В.В. Мавродин пишут о двух крепостях (Ламбин, 1843, с. 650-651; Мавродин, 1988, с. 138). В некоторых исследованиях сообщается, что князь А. Бекович-Черкасский заложил три города - в урочище Тюк-Караган, в заливе Александрбай и на Красных водах (Безгин, 1891, с. 44).

По всей видимости, первым сочинением, в котором появилась версия о трех крепостях, стал труд Ф.И. Соймонова. В нем упоминается не только о строительстве русских городов в заливах Тюк-Караганском и Красно- 
водском, но и о том, что в 120 верстах от Тюк-Карагана находился залив, который соединялся с Каспийским морем узким каналом, и именно там князь А. Бекович-Черкасский построил еще одну крепость. «Место казалось по своему положению быть безопасным, - пишет Ф.И. Соймонов. - Для того определил там Бекевич токмо три роты гарнизону под командою одного Маиора» (Соймонов, 1763, с. 16).

Эти сведения впоследствии приводились в других исследованиях. В частности, В.В. Мавродин называл одну из двух крепостей именно Александровской (Мавродин, 1988, с. 138). Однако документальных подтверждений о закладке города или крепости в заливе Александрбай не обнаружено.

В связи с этим следует отметить, что труд Ф.И. Соймонова, вышедший в 1763 г., подвергался редактированию со стороны профессора Г.Ф. Миллера, который выбирал информацию из его журналов, относящихся к периоду службы на Каспийском море, и дополнял их сведениями из различных источников, в том числе словесными объявлениями генерал-майора А.И. Тевкелева, которой был участником каспийской экспедиции князя А. БековичаЧеркасского. Не исключено, что с течением времени подробности событий 1716 г. могли утратиться. Косвенным свидетельством этого может служить тот факт, что в труде Ф.И. Соймонова не приводится фамилия майора, который якобы возглавил строительство крепости в заливе Александрбай. Но приводятся точные сведения о командном составе полков, которые основали крепости в заливе Тюк-Караганском и Красноводском.

В официальной переписке, относящейся к рассматриваемым событиям, фигурируют упоминания лишь двух крепостей: Святого Петра в заливе Тюк-Караган и Красноводской в одноименном заливе Каспийского моря. Как следует из показаний туркмена Тлева Шейдякова, данных астраханскому обер-коменданту М.И. Чирикову в августе 1717 г., туркменам ничего не было известно о третьей русской крепости. Т. Шейдяков сообщил, что «при них де на Тюк-Карагани и на Красных водах царского величества ратные люди все в добром здоровье». Туркменский старшина Булат Бахши в письме к астраханским властям в сентябре 1717 г. также сообщал, что князь А. Бекович-Черкасский прибыл только в Тюк-Караган и на Красные воды (РТО, 1963, с. 32-33). В донесении казанского губернатора П.С. Салтыкова президенту Адмиралтейств-коллегии в октябре 1717 г. говорилось, что послы хивинского хана Ширгазы предъявили претензии князю А. Бековичу-Черкасскому в том, что он не только пришел с войском к ним в страну, но и «построил-де ж в Тюк-Карагане и в Красных Водах два города, а и в Хиве-де то ж учинит» (РТО, 1963, с. 34).

Так откуда могли взяться сведения о третьей крепости? Командир Коротояцкого полка полковник фон дер Виден в донесении президенту Адмиралтейств-коллегии 30 апреля 1718 г. отмечал, что прибыл в урочище Красные воды в 1716 г. с двумя полками, «а в тех полках было по прибытии по половине 
полков, а другие были не в приезде, понеже погодою морскою разнесло и выметало по берегам на персидской кряж и на трухменской» (РТО, 1963, с. 35). Аналогичные сведения приводит и поручик Коротояцкого полка Ф. Исингельдеев. Он сообщает, что полковник фон дер Виден перезимовал с имевшимися при нем людьми в Красноводском заливе,

«а за вышепомянутыми-де офицерами и солдаты, коих разбило на море и занесло на персидскую сторону и на трухменский кряж; по ведомостям, полковник фон дер Виден посылал капитана Сурмина, порутчика Зелейского да прапорщика Манцена с солдаты с осьмью десять человек на трех бусах и оные возвратились, и с ними в тое ж Красновоцкую крепость на брегантинах и других судах прибыли тех полков штаб- и обер-офицеров и солдат малое число» (PTO, 1963, с. 42)

По всей видимости, вынужденное пристанище кораблей к берегу могло быть принято впоследствии за основание третьей крепости на Восточном побережье Каспийского моря. В этой связи уместно привести сведения из

«Лексикона» В.Н. Татищева, в котором указывается, что залив Александрбай назван «от того, что в 17... году князь Александр Бекович Черкаской во оном месте имел пристань» (Татищев, 1979, с. 159).

Интересно, что сам князь А. Бекович-Черкасский докладывал Петру I о закладке лишь одного города. «По указу вашего величества приехали до указанного места на транспортных судах прошедшего месяца октября 20-го дня, - отмечал он в послании от 18 ноября 1716 г. - Зачали крепость при гавани прежнего устья Аму-реки, какова крепость зачата и в котором месте, тому при сем послан рисунок» (РТО, 1963, с. 29).

По какой причине князь А. Бекович-Черкасский умолчал о строительстве не одной, а двух крепостей не ясно. Но ко времени направления письма Петру I им были заложены уже две крепости, а не одна. Интересно, что в именном указе Петра I, объявленном из Сената 15 ноября 1717 г. тоже идет речь лишь об одной «новопостроенной крепости при море Каспийском» (ПСЗРИ, 1830, c. 518). По всей видимости, Петр I был уверен в том, что князь А. Бекович-Черкасский действовал в соответствии с его указом и заложил на каспийском побережье одну крепость.

В связи с этим обращает на себя внимание то обстоятельство, что князь А. Бекович-Черкасский с самого начала отошел от пунктов указа, данного Петром I. Этот указ предусматривал закладку новых городов вдоль русла реки Аму-Дарьи, начиная от Каспийского моря и до плотины, тогда как князь А. Бекович-Черкасский заложил их вдоль Восточного побережья Каспийского моря. Город на побережье Каспийского моря предписывалось основать в расчете на одну тысячу человек, но князь А. Бекович-Черкасский оставил для градостроительства и тем фактически выключил из состава своих сил три регулярных полка. В итоге он отправился в Хивинское ханство с иррегуляр- 
Journal of Frontier Studies. 2022. No 1 | ISSN: 2500-0225

Empire on the Move | https://doi.org/10.46539/jfs.v7i1.367

ными отрядами, состоявшими из казаков и тюркских народов, и «шквадроном» из военнопленных, захваченных в ходе сражений Северной войны.

\section{На восточном рубеже Каспия}

Русские полки оказались в непривычной ситуации на Восточном побережье Каспийского моря. Их командование отдавало отчет, что они находятся на чужой территории. Полковник фон дер Виден указывал в своем донесении, что князь А. Бекович-Черкасский отправился из Красноводского залива сухим путем в Астрахань, а «меня оставил на той косе морской, которая под владением трухменских народов, з двумя полками, с Коротояцким да с Астраханским» (РТО, 1963, с. 35).

Отношение туркмен к строительству на Восточном побережье Каспия, фактически в местах их проживания русских городов поначалу было нейтральным. 18 ноября 1716 г. князь А. Бекович-Черкасский докладывал Петру I о дружественном отношении туркмен к России. Они, по его словам, помогали перевозить людей и провиант с разбитых судов на своих подводах

«без многого запросу дачею», отказались повиноваться приказам посланцев хивинского хана. Сами туркмены сообщали о фактах содействия экспедиции князя А. Бековича-Черкасского (РТО, 1963, с. 29-30).

Совсем по-другому воспринималось строительство русских городов в Хивинском ханстве, где посланникам князя А. Бековича-Черкасского задавали прямой вопрос: «Для чего вы города строите на чужой земле?» (Соловьев, 1993, с. 343).

Между тем строительство новых городов продолжалось. К середине января 1717 г. в Тюк-Караганском заливе крепость Святого Петра уже имела некоторые очертания: «В том месте города сделано было одной стены сажен на сорок или чем малым болши, вышиною два аршина, кладен камень не смазывая» (Гистория, 2004, с. 605). В Красноводском заливе основным материалом для строительства крепости служил морской ракушечник, так как там «лесу и дерну и камышу и травы, кроме помянутой ракушки, на той косе много, к городовому делу способного нет». По свидетельству полковника вон дер Видена, ракушечник был «хуже песка». Использовать его для «насыпи валу без дерева и фашин или без дерну удержать было и на защищение людем насыпать вал высотою в настоящую меру невозможно» (РТО, 1963, с. 43).

Гарнизоны прикаспийских городов испытывали серьезные сложности с адаптацией на Восточном побережье Каспийского моря, оказавшись в крайне непривычной обстановке. Им приходилось жить в условиях дефицита пресной воды и дров, зимовать «со многою нуждою в одних полковых палатках». Недостаток пригодной для питья воды пытались компенсировать рытьем новых колодцев, так как «больши трех дней ис колодца брать и пить воды не велят, а старые закапывают», сообщали очевидцы. Отсутствие леса созда- 
вало проблемы с обеспечение дровами. Их недостаток гарнизоны крепостей компенсировали рытьем корней трав (РТО, 1963, с. 42)

Среди личного состава наблюдалась высокая смертность. Так, покидая в конце 1716 г. расположение полка у Красных вод, поручик А. Кожин отметил, что в том месте осталось больных солдат и матросов «человек 3 двести» и умерло «з двадцать» (Гистория, 2004, с. 605). 18 января 1717 г. князь А. БековичЧеркасский посетил Тюк-Караган, где оставил полк полковника Ф.С. Хрущева. Начальник экспедиции нашел в том месте больных солдат и матросов «с семьсот человек», 120 к тому времени уже умерли (Гистория, 2004, с. 605). 25 июня 1717 г. астраханский обер-комендант М.И. Чириков докладывал, что в городке на Тюк-Карагане по состоянию на май того года померло больше пятисот офицеров и солдат. В другом его донесении говорилось, что «на Красных водах людей померло гораздо много». Из письма полковника фон дер Видена следовало, что в городке осталось около двухсот здоровых человек в обоих полках, «да больных семьсот человек, а те все померли» (Гистория, 2004, с. 596).

На фоне высокой смертности в гарнизонах прикаспийских городов сложилась парадоксальная ситуация: при недостатке питьевой воды наблюдался излишек провизии. «А провианту сказывают, которой есть ныне на Красных водах, и тово правианту на те люди будет на два года, и болше правианту не требуют», - докладывали из Астрахани (Бучков, 1871, с. 301-302).

Гибель в 1717 г. экспедиции А. Бековича-Черкасского в Хивинском ханстве резко изменила судьбу русских городов на Восточном побережье Каспийского моря. Отношение туркмен к российским городам стало меняться.

\begin{abstract}
«А как я известие получил про него, князя Черкасского, что хивинцы со всем войском ево побили и в полон побрали, - отмечал полковник фон дер Виден, тако ж трухменцы, про которых писал он, князь, бутто курант (Коран. И.Т.) целовали и поддались под руку его, царского величества, те стали людей наших в полон брать, их бить и на крепость приступать сухим путем и морем» (PTO, 1963, с. 35).
\end{abstract}

Так, 29 августа 1717 г. туркмены неожиданно напали на отряд солдат, высланный из Красноводской крепости «для вырывания вместо дров коренья травного». В плен попали 30 человек. На другой день к крепости приехали туркмены, в числе которых был мурза Бутузбек, которые рассказали, что князя А. Бековича-Черкасского, «и при нем будучее войско хивинцы побили, а достальных всех разобрали по рукам». Спустя пять дней ту же информацию доставил в Красноводскую крепость туркменский Ард-мурза. Он сообщил о готовящемся туркменском нападении на Красноводскую крепость, «что их в той крепости хотят доставать уже, и для того вышепомянутой Бутузбек водою в близости стоят и собираетца, и чтоб они от того имели осторожность» (PTO, 1963, с. 42). 
Командование крепости вынуждено было принять необходимые меры предосторожности. И «от тех неприятельских людей имели они в той крепости денно и нощно непрестанную крепкую осторожность, - сообщил прапорщик Ф. Исингельдеев, - и для того за недостатком фитиля полковые солдацкие палатки к пушкам и к гранадерам собирая с рот вместо фитиля жгли» (PTO, 1963, с. 42).

После получения в 1717 г. известий о гибели в Хивинском ханстве экспедиции князя А. Бековича-Черкасского казанский губернатор П.С. Салтыков направляет в Сенат запросы, как быть в этой ситуации с гарнизонами прикаспийских городов. Сенат приказал ему пополнить состав полка рекрутами, крепость Святого Петра содержать, как возможно, а о другой крепости, построенной в ходе экспедиции А. Бековича-Черкасского, «в том указе ничего не написано - содержать ли ее, или людей вывесть, также и кого туда камандиром послать» (Гистория, 2004, с. 598).

Между тем выяснилось, что направленные для изучения обстановки из Астрахани в прикаспийские города офицеры 3 ноября возвратились обратно «для того что за льдом ехать им в крепость невозможно». В то же время до Астрахани сумели добраться из тюк-караганской крепости Святого Петра капитан Д. Камецкой, а из Красноводской крепости сержант С. Яковлев. Их сообщения не оставляли сомнений в том, что гарнизоны прикаспийских городов оказались во враждебном окружении кочевых народов.

Капитан Д. Камецкой сообщил, что при его отъезде обстановка была мирной, но «было ведение чрез трухменцов, что на крепость Святого Петра трухменцы збираются войною». В его бытность там офицеры и солдаты всегда стояли на стенах, а крепость к этому времени была построена наполовину. После появления в ней туркмена Ходжи Непеса, рассказавшего о гибели экспедиции князя А. Бековича-Черкасского, на другой день был послан отряд солдат и казаков за глиною с прапорщиком Обуховым, которые подверглись нападению туркмен. На следующий день они привезли к крепости взятых ими двух солдат и одного казака. С того времени гарнизон стал «иметь от тех трухменцов опасение и на тое крепость нападения». Его командир

\begin{abstract}
«за умалением людей» перестроил крепостные укрепления в сторону их уменьшения, построил на берегу гавани больверк из казарм, между которыми установил заборы, около крепости начали рыть ров. На вооружении гарнизона крепости находилось 11 пушек, у солдат было по сорок патронов на человека, не считая картечи (Гистория, 2004, с. 608-609).
\end{abstract}

Сержант С. Яковлев рассказал, что посланная при нем за дровами из Красноводской крепости на двух бригантинах партия подверглась нападению туркмен, которые взяли в плен 26 человек. После этого они вызвали гарнизон на переговоры, во время которых рассказали, «что де хивинцы лейбгвардии капитана Черкаского со всем войском разобрали по рукам, не дошед до Хивы». Вскоре вокруг Красноводской крепости начались военные действия: 
туркмены приступали к крепости с суши и со стороны моря. Им удалось ворваться в неё, но гарнизон смог вытеснить их обратно, убив четырех человек. Среди погибших со стороны туркмен оказался и их предводитель - родной брат текей-юмутского мурзы. При этом на той «баталии» было ранено стрелами 20 солдат Коротояцкого полка.

Туркмены держали Красноводскую крепость в осаде неделю, после чего ушли в свои улусы. С уходом противника в крепости состоялся военный совет, по итогам которого командир гарнизона полковник фон дер Виден, «дабы и последних людей не утратить и ружья и омуниции не отдать неприятелю», принял решение оставить крепость. 3 октября 1717 г. на 13 судах остатки Красноводского гарнизона отплыли в Астрахань (Гистория, 2004, с. 609, РТО, 1963, c. $42-43)$.

Не зная обстановки в прикаспийских городах, Сенат 15 ноября 1717 г. приказал

\begin{abstract}
«Новопостроенную крепость при море Каспийском содержать как возможно, и оную не покидать, а между тем временем нынешнею зимою послать нарочного из офицеров доброго и с ним Александра Кожина для осмотрения той крепости и в ней людей, и уведомиться подлинно, возможно ль оную содержать впредь без большой трудности или нет, а буде не мочно за какою нуждою необходимою, тогда тому посланному офицеру людей из той крепости вывесть и привесть с собою в Астрахань (покамест жары не наступили)» (ПСЗРИ, 1830, c. 518).
\end{abstract}

K моменту получения данного указа в крепости Святого Петра на 29 ноября 1717 года оставалось 497 человек из числа Казанского полка и 100 яицких казаков (Гистория, 2004, с. 609). Ее гарнизон выдержал еще одну зимовку. Крепость Святого Петра упоминается в переписке астраханских и казанских властей в апреле 1718 г. (Бучков, 1871, с. 398). По всей видимости, впоследствии ее гарнизон был выведен в Астрахань.

Что касается Красноводского гарнизона, то он не смог добраться сразу до Астрахани, а вынужден был зазимовать на Западном побережье Каспийского моря, куда были занесены штормом суда, на которых они шли в Астрахань. В 1718 г. в Астрахань смогли вернуться меньше 300 человек из числа Коротояцкого полка. Данные об Астраханском полку, который также был в составе Красноводского гарнизона, в дошедших до нас источниках не приводятся.

\title{
Выводы
}

Судьба русских городов на Восточном побережье Каспийского моря весьма поучительна. Они были основаны во исполнение воли Петра I по инициативе князя А. Бековича-Черкасского, который фактически превысил полномочия, данные ему Петром I, заложив города не в направлении Хивинского ханства, а вдоль Восточного побережья Каспийского моря. 
Их гарнизоны оказались в непривычной местности, без необходимых запасов воды и дров, не имели между собой коммуникации, но стойко переносили все тяготы службы, в полной мере испытав на себе изменчивость отношения туркмен к российской экспансии на Восточное побережье Каспийского моря. В итоге командование Красноводской крепости, не дожидаясь указаний Петра I, покинуло город и вернулось с остатками гарнизона в Астрахань. Та же судьба, по всей видимости, постигла и гарнизон крепости Святого Петра в Тюк-Караганском заливе.

Таким образом, Петр I, располагая мощной армией и флотом, замахнувшись на решение задачи по поиску пути в Индию через Среднюю Азию, не смог довести ее до логического завершения. Попытка России закрепиться на Восточном побережье Каспийского моря и наладить водный путь в Индию в его эпоху не увенчалась успехом. Но российский император не откажется от идеи продвижения в Индию из Каспийского бассейна. Спустя пять лет он вновь предпримет активные усилия по закреплению за Россией на этот раз Западного и Южного побережий Каспийского моря.

\section{Список литературы}

Андреев, А. А., Янченко, Д. Г., Даудов, А. Х., Шорохов, В. А., \& Кибинь, А. С. (2016). К истории первых русских крепостей на восточном побережье Каспийского моря. Былые годы, 39, 5-13.

Анисимов, Е. В. (2019). Пётр Великий и основы его восточной политики. Пётр I и Восток. Материалы XI Международного петровского конгресса, 11-16.

Безгин, И. Г. (1891). Князя Бековича-Черкасского экспедищия в Хиву и посольства флота поручика Кожина и мурзы Тевкелева в Индию к Великому Моголу. (1714-1717). Библиографическая монография. Типография Р. Голике.

Буганов, В. И. (1989). Петр Великий и его время. Наука.

Бычков, А. Ф. (Ред.). (1871). Материалы Военно-учетного архива Главного итаба. Том. І. Печатня В.И. Головина.

Голиков, И. И. (1788). Деяния Петра Великого. В 12 частях. Часть 5. В Университетской типографии у Н. Новикова.

Жуковский, С. В. (1915). Сношения России с Хивой и Бухарой за последнее трехсотлетие. Труды Общества Русских Ориенталистов.

Князьков, С. А. (1914). Очерки из истории Петра Великого и его времени. Издание 2-е исправленное и дополненное. Издание книжного магазина П.В. Луковникова.

Князьков, С. А. (1991). Из прошлого русской земли. Время Петра Великого. Книга для чтения по русской истории в школе и дома. Репринтное воспроизведение издания 1909 г. Планета.

Ламбин, Н. П. (1843). История Петра Великого.

Мавродин, В. В. (1988). Рождение новой России. Издательство Ленинградского университета.

Павленко, Н. И. (1976). Пётр Первый. 2-е изд., испр. Молодая гвардия. 
Платонов, С. Ф. (1917). Учебник русской истории для средней школы. Курс систематический в двух частях с приложением восъли карт. Изд. 9-е, дополненное. Типография Я. Башмаков и Ко.

Платонов, С. Ф. (1993). Лекции по русской истории. Высшая школа.

Полное собрание законов Российской Илперии (ПСЗРИ). Том 5. (1830).

Преображенский, А. А., \& Майкова, Т. С. (Ред.). (2004). Гистория свейской войны (Поденная записка Петра Великого) (1-е изд.). «Кругъ».

Русско-туркменские отношения в XVIII-XIX вв. (До присоединения Турклении к России) (PTO). (1963). АН ТуркмССР.

Соймонов, Ф. И. (1763). Описание Каспийского моря и чиненных на оном Российских завоеваний, яко часть истории государя илператора Петра Великого, трудали Тайного Советника, Губернатора Сибири и Ордена святого Александра Кавалера Федора Ивановича Соймонова, выбранное из журнала Его Превосходительства, в бытность его службы морским Офищером, и с внесенныли, где потребно было, дополнениями Академии Наук КонференцСекретаря, Профессора Истории и Историографии, Г.Ф. Миллера. Императорская академия наук.

Соловьев, С. М. (1993). Сочинения. В 18 кн. Кн. ІХ. История России с древнейших времен. Т. 17-18 (И. Д. Ковальченко \& С. С. Дмитриев, Ред.). Мысль.

Татищев, В. Н. (1979). Избранные произведения. Наука.

\section{References}

Andreev, A. A., Yanchenko, D. G., Daudov, A. H., Shorokhov, V. A., \& Kibin, A. S. (2016). To the History of the First Russian Fortresses on the Eastern Coast of the Caspian Sea. Bylye gody, 39, 5-13. (In Russian).

Anisimov, E. V. (2019). Peter the Great and the Foundations of His Eastern Policy. Peter the Great and the East. Proceedings of the XI International Congress of Peter the Great, 11-16. (In Russian).

Bezgin, I. G. (1891). Knyaz Bekovich-Cherkassky's expedition to Khiva and the fleet embassies of Lieutenant Kozhin and Murza Tevkelev to India to the Great Mogul. (1714-1717). Bibliographic monograph. R. Golicke's printing house. (In Russian).

Buganov, V. I. (1989). Peter the Great and his age. Nauka. (In Russian).

Bychkov, A. F. (Ed.). (1871). Proceedings of the Military Records Archive of the General Staff. Vol. I. Printing house of V.I. Golovin. (In Russian).

Complete Collection of Laws of the Russian Empire (CCLRE). Vol. 5. (1830). (In Russian).

Golikov, I. I. (1788). The Acts of Peter the Great. In 12 parts. Part 5. At the University Print Shop of N. Novikov. (In Russian).

Knyazkov, S. A. (1914). Essays on Peter the Great and his time. 2nd revised and enlarged edition. Publication of P.V. Lukovnikov's bookshop. (In Russian).

Knyazkov, S. A. (1991). From the past of the Russian land. The time of Peter the Great. A Reading Book for Russian History at School and at Home. A reprint of the 1909 edition. Planet. (In Russian).

Lambin, N. P. (1843). History of Peter the Great. (In Russian). 
Mavrodin, V. V. (1988). The birth of a new Russia. Leningrad University Press. (In Russian).

Pavlenko, N. I. (1976). Peter the First. 2nd ed. revised. Molodaya Gvardiya. (In Russian).

Platonov, S. F. (1917). Textbook of Russian History for Middle School. A systematic course in two parts with eight maps. Ed. 9, supplemented. Y. Bashmakov and Co. Bashmakov \& Co. (In Russian).

Platonov, S. F. (1993). Lectures on Russian history. High school. (In Russian).

Preobrazhensky, A. A., \& Maykova, T. S. (Eds.). (2004). Histories of the Nordic War (Peter the Great's Endeavour Note) (1st ed.). "Krug". (In Russian).

Russian-Turkmen relations in the 18th-19th centuries. (Before Turkmenistan's accession to Russia) (RTO). (1963). Academy of Sciences of Turkmen SSR. (In Russian).

Soloviev, S. M. (1993). Essays. In 18 Knees, Book IX. History of Russia from the most ancient times. Vols. 17-18 (I. D. Kovalchenko \& S. S. Dmitriev, Ed.). Mysl. (In Russian).

Soymonov, F. I. (1763). The Description of the Caspian Sea and the Russian Achievements, as Part of the History of Sovereign Emperor Peter the Great, by the Privy Counsellor, Governor of Siberia and the Order of St. Alexander Cavalier Fedor Ivanovich Soimonov, selected from the journal of His Excellency, when he was a Naval Officer, and with additions, where necessary, of the Conference Secretary, Professor of History and Historiography, G.F. Miller. Imperial Academy of Sciences. (In Russian).

Tatishchev, V. N. (1979). Selected works. Nauka. (In Russian).

Zhukovsky, S. V. (1915). Russia's relations with Khiva and Bukhara over the last three centuries. Proceedings of the Society of Russian Orientalists. (In Russian). 